\begin{tabular}{|l|l|l|}
\hline \multicolumn{2}{|c|}{ PublisherInfo } \\
\hline \hline PublisherName & $:$ & BioMed Central \\
\hline \hline PublisherLocation & $:$ & London \\
\hline \hline PublisherImprintName & $:$ & BioMed Central \\
\hline \hline
\end{tabular}

\title{
Genome evolution goes local
}

\begin{tabular}{|l|l|l||}
\hline \multicolumn{2}{|c|}{ ArticleInfo } \\
\hline \hline ArticleID & $:$ & 3698 \\
\hline \hline ArticleDOI & $:$ & $10.1186 /$ gb-spotlight-20000609-01 \\
\hline \hline ArticleCitationID & $:$ & spotlight-20000609-01 \\
\hline \hline ArticleSequenceNumber & $:$ & 135 \\
\hline \hline ArticleCategory & $:$ & Research news \\
\hline \hline ArticleFirstPage & $:$ & 1 \\
\hline \hline ArticleLastPage & $:$ & 2 \\
\hline \hline & & RegistrationDate : 2000-06-09 \\
ArticleHistory & $:$ & OnlineDate \\
\hline \hline ArticleCopyright & $:$ & BioMed Central Ltd2000-06-09 \\
\hline \hline ArticleGrants & $:$ & \\
\hline \hline ArticleContext & $:$ & 130591111 \\
\hline \hline
\end{tabular}


Retrotransposons take up over $70 \%$ of the barley genome, so any change in their numbers can have a significant impact on genome size. In the June 6 issue of the Proceedings of the National Academy of Sciences], Kalendar et al. report that the copy number of one retrotransposon, $B A R E-1$, varies nearly three-fold in the wild barley found in a $300 \mathrm{~m}$ transect of a single Israeli canyon (Proc. Natl. Acad. Sci. USA 2000, 97:6603-6607). Drier areas higher in the canyon show the highest copy numbers, perhaps because the stress-response element in the $B A R E-1$ promoter induces more transposition in these plants. The expansion may have adaptive utility for plants in arid environments, which grow primarily in the cool, wet winters when growth rates are slowed by the lower temperature. The retrotransposon expansion and thus large genome size should result in larger cell sizes, which can offset the slower growth rate.

\section{References}

1. Retrotransposon BARE-1 and Its Role in Genome Evolution in the Genus Hordeum.

2. Proceedings of the National Academy of Sciences, [http://www.pnas.org/] 